Науковий вісник НЛтУ України
Scientific Bulletin of UNFU
https://nv.nltu.edu.ua
$\begin{aligned} & \text { https://doi.org/10.15421/40281026 } \\ & \text { Article received 12.11.2018 p. } \\ & \text { Article accepted 29.11.2018 p. } \\ & \text { удк 37.091.2:172.15 }\end{aligned}$

Л. Б. Шептицька, Н. Г. Захарчин, О. А. Чаплик

Національний лісотехнічний університет Украӥни, м. Львів, Украӥна

\title{
СИСТЕМА НАЦІОНАЛЬНО-ПАТРІОТИЧНОГО ВИХОВАННЯ У ВИЩОМУ НАВЧАЛЬНОМУ ЗАКЛАДІ ЛІСОТЕХНІЧНОГО ПРОФІЛЮ
}

\begin{abstract}
Враховуючи потреби часу і важливість формування світогляду молоді, на прикладі Національного лісотехнічного університету України відстежено процес формування системи національно-патріотичного виховання студентів впродовж періоду його становлення. Опираючись на нормативно-правові акти, обгрунтовано потребу створення Ради 3 організації виховної роботи та залучення до цієї роботи Координаційної ради кафедр гуманітарно-соціальних дисциплін та інших підрозділів університету. Окреслено основні напрями виховання студентів: національно-громадянський, військово-патріотичний, екологічний, громадянсько-правовий та ін., особливу роль серед яких відведено екологічному. Наведено основні форми вживання виховних заходів в університеті. Доведено необхідність активізації подальшої роботи в напрямі національно-патріотичного виховання. Окреслено роботу колективу університету в пошуку нових форм та методів здійснення виховних заходів та вирішення проблеми подолання пасивності та інертності частини студентського середовища. Стверджено, що активна участь студентів у позанавчальному житті університету також сприяє формуванню у них Soft Skills (м'яких навичок), в яких зацікавлені сучасні роботодавці. Акцентовано увагу на перспективі створення арт-студії та молодіжного центру для співпраці студент - викладач на виховній ниві.
\end{abstract}

Ключові слова: виховання; національно-патріотичне виховання; екологічне виховання; НЛТУ України.

Вступ. Виховання молоді було і залишається важливою ділянкою роботи в закладах вищої освіти. Змінюються пріоритети, цінності. Політична ситуація в країні та військова агресія на Сході диктують нові вимоги у цьому напрямі роботи. Окрім цього, сучасний студент це не тільки гармонійно розвинена, високоосвічена, соціально активна людина, яка здатна до саморозвитку і самовдосконалення, але й особистість, яка має своє бачення і критичні зауваження щодо ії виховання. Тому виховна робота сьогодні потребує пошуку нових форм, наповнення новим змістом і злагодженої комплексної роботи всіх структурних підрозділів сучасного університету.

Дослідженням тематики виховної роботи у вищих навчальних закладах займались переважно українські науковці. Специфіку планування виховної роботи в закладах вищої освіти на засадах комплексності, системності та на підставі особистісно орієнтованих принципів розглядає Р. Сопівник (Sopivnyk, 2016). Теоретикометодичні засади реалізації принципу єдності навчання і виховання у формуванні професійно орієнтованого іншомовного навчального середовища в умовах університету досліджує Л. Петько (Petko, 2017). О. Попова аргументує важливість освіти у формуванні сучасної національної ідентичності (Popova, 2017).

На позааудиторній роботі з громадянського вихо- вання акцентують увагу О. Корішко, Є. Палаткін (Korkishko \& Palatkin, 2017). Дослідники стверджують, що така робота сприяє розширенню потреби студентів у політичних, правових, економічних, соціально-психологічних і культурологічних знаннях, спілкуванні, прищепленню практичних навичок взаємодії особи 3 державою та суспільством, вихованню громадянської свідомості (Korkishko \& Palatkin, 2017). Специфіку позааудиторної виховної роботи у вищому закладі аналізує Л. В. Прокофєва (Prokofyeva, 2017).

Мета дослідження - показати особливості формування системи національно-патріотичного виховання студентів у закладах вищої освіти лісотехнічного профілю на прикладі Національного лісотехнічного університету України з часу проголошення незалежності України і до сьогодення.

Викладення основного матеріалу дослідження. Впродовж 25 років в університеті сформувалася і діє система національно-патріотичного виховання, яка покликана забезпечувати становлення самодостатнього громадянина - патріота України. 3 часу отримання навчальним закладом статусу "університет" виховну роботу визначали нормативно-правовими документами - Законом України "Про освіту", Державною національною програмою "Освіта" ("Україна XXI століття") 1993 р., Указом Президента України "Про основні напрями ре-

Інформація про авторів:

Шептицька Любов Богданівна, канд. істор. наук, доцент, завідувач кафедри історії України, політології та права.

Email: shlubov@ukr.net

Захарчин Наталія Генадіївна, канд. істор. наук, доцент, кафедра історії України, політології та права. Email: zakharchin@ukr.net Чаплик Ольга Андріївна, ст. викладач, кафедра іноземних мов. Email: chaplykolga@gmail.com

Цитування за ДСтУ: Шептицька Л. Б., Захарчин Н. Г., Чаплик О. А. Система національно-патріотичного виховання у вищому навчальному закладі лісотехнічного профілю. Науковий вісник НЛтУ України. 2018, т. 28, № 10. С. 135-138.

Citation APA: Sheptytska, L. B., Zakharchyn, N. G., \& Chaplyk, O. A. (2018). The system of national and patriotic education in higher educational institutions of forestry. Scientific Bulletin of UNFU, 28(10), 135-138. https://doi.org/10.15421/40281026 
формування вищої освіти" 1995 р. та методичними рекомендаціями Міністерства освіти України.

У 1993 р. на підставі наказу Міністерства освіти України № 395 "Про удосконалення керівництва виховною роботою" від 1993 р. в Українському державному лісотехнічному університеті було створено Раду з організації виховної роботи під керівництвом проректора 3 гуманітарної освіти та виховання. У межах факультетів діяли ради наставників академічних груп, які очолювали заступники деканів 3 виховної роботи. 3 метою ознайомлення наставників із новою парадигмою виховання при кафедрі філософії було створено постійно діючий психолого-педагогічний семінар. Для студентів першого курсу розроблено і запропоновано програму адаптаційного курсу, студенти другого курсу ознайомлювалися з основами християнської етики. Для старшокурсників запроваджено спецкурс "Українська національна ідея: історія і сучасність". 3 метою врахування думки студентів щодо змісту і форм виховної роботи при кафедрі культурології було створено центр соціологічних досліджень.

Системний підхід до виховної роботи започаткував завідувач кафедри історії України, політології та права НЛТУ України проф. В. О. Кондратюк, який упродовж багатьох років координував цю важливу ділянку роботи, наполегливо домагався реалізації цілей національно-патріотичного та громадянського виховання студентів університету. Тоді пріоритетним вважалося національно-громадянське виховання (Zakon Ukrainy, 1991), яке було спрямоване на підготовку інтелігенції з чіткою громадянською позицією, створенням умов для розвитку загальної культури студентської молоді. Основними формами роботи були урочисті вечори до пам'ятних дат, посвяти в студенти, екскурсії, студентські спартакіади, день першокурсника, відзначення свят за народним календарем та ін.

Сьогодні в університеті органічно впроваджено єдину політику навчання і виховання, що відображено у "Планах роботи та заходах щодо реалізації системи національно-патріотичного виховання студентів НЛТУ України", які щорічно затверджує ректор. Ці заходи планують і вживають в університеті відповідно до Законів України, Указів Президента України (зокрема "Про Стратегію національно-патріотичного виховання дітей та молоді на 2016-2020 роки"), Постанов Верховної Ради України, наказів та листів Міністерства освіти і науки України, розпоряджень Львівської обласної адміністрації та 3 урахуванням принципів, мети і завдань "Концепції національно-патріотичного виховання дітей та молоді".

Організаційно-методичне забезпечення виховного процесу студентів здійснює Рада університету з виховної роботи, головою якої $є$ проректор з науково-педагогічної виховної роботи та міжнародних зв'язків, та Координаційна рада кафедр гуманітарно-соціальних дисциплін. Важливо, що до цієї роботи активно долучається профком студентів та співробітників, студентське самоврядування.

Як відзначають у Міністерстві освіти і науки України, "серед виховних напрямів сьогодні найбільш актуальними виступають патріотичне, громадянське виховання як стрижневі, основоположні, що відповідають як нагальним вимогам і викликам сучасності, так і закладають підвалини для формування свідомості нинішніх і прийдешніх поколінь, які розглядатимуть державу (patria) як запоруку власного особистісного розвитку, що спирається на ідеї гуманізму, соціального добробуту, демократії, свободи, толерантності, виваженості, відповідальності, здорового способу життя, готовності до змін" (Nakaz, 2016). Саме такі принципи роботи активно впроваджуються у життя в НЛТУ України сьогодні.

Зважаючи на ситуацію в державі, в національно-патріотичному вихованні пріоритетним напрямом в університеті став військово-патріотичний, зорієнтований на формування у студентів високого ідеалу служіння українському народові, готовності будь-коли стати на захист суверенітету і територіальної цілісності нашої держави. Викладачі та студенти активно долучаються до волонтерської діяльності. Навчально-наукові інститути, кафедри, бібліотека та інші структурні підрозділи університету, які збором коштів, поїздками в зону Операції об'єднаних сил, відвідуванням поранених у госпіталях, плетінням сіток, купівлею медикаментів, тепловізорів, та іншими благодійними акціями, власним прикладом формують патріотично орієнтований процес виховання студентів, залучаючи молодих людей до цієї діяльності.

Поряд із зміною напрямів з'явилися різноманітні форми проведення виховних заходів. Пріоритетну роль у вихованні студентів відіграють кафедри гуманітарносоціальних дисциплін, які комплексно охоплюють навчальний і позанавчальний процес, впроваджують нові технології проблемного навчання та постійно урізноманітнюють цей напрям роботи.

Традиційні урочисті академії (до дня захисника України, річниці ЗУНР, УНР, 100-річчя битви під Крутами та ін.) отримують нові формати із запрошеними бійцями ООС, зокрема університетськими співробітниками i викладачами; переглядами короткометражних фільмів; постановкою студентами сцен до пам'ятних дат.

В університеті проводяться круглі столи та теоретичні конференції, семінари та лекторії, перегляд та обговорення документальних і художніх фільмів "Патріapx", "Україна: становлення нації", "Легіон. Хроніки Української Галицької Армії 1918-1919", "Серце матері Гонгадзе" та інші. Традиційним стало проведення флешмобів: до 200-річчя від дня народження М. Вербицького (2015 р.), вшанування української символіки (2016 р.), Всесвітнього Дня вишиванки (2017 р.).

Особливий інтерес для студентів мають зустрічі з відомими людьми, політиками (з першим космонавтом Героєм України Леонідом Каденюком, зв'язковою УПА Дарією Гермак, бійцем УПА Олесем Гумницьким, народним депутатом Олегом Березюком та ін.).

Мета національно-патріотичного виховання студентів успішно реалізовується через проведення Тижня права, Тижня іноземних мов, "Сковородинських читань" тощо. Конкурси, богословські зустрічі, засідання клубів, виставки-конкурси студентських проектів, презентації, спартакіади - це не повний перелік тих форм, що сьогодні презентують кафедри у виховній роботі.

Глобальні зміни техногенного характеру, екологічні проблеми в Україні та світі потребують нових підходів до організації форм і методів національно-патріотичного виховання. Варто акцентувати увагу на екологічному вихованні, яке $\epsilon$ "...найважливішим завданням не тільки для студентів і викладачів, а й для професіоналів будь-якої сфери діяльності, для будь-якої людини, бо 
вони є стимулятором доброзичливого ставлення до оточуючих та навколишнього середовища" (Pashkov \& Trofimov, 2016). Воно стало невід'ємною частиною навчально-виховного процесу в університеті. Круглі столи, екофестивалі ("Корінці добра", кафедра історії України, політології та права); студентські лекторії (кафедра філософії та психології); конкурси творчих робіт студентів $з$ екологічною складовою, екологічні практики (кафедра дизайну, кафедра соціології та культурологіi); конкурс студентських презентацій, природоохоронні акції ("Посади, друже, дерево ДУЖЕ", кафедра іноземних мов); участь у проекті "Львову личить зелене" (кафедра обліку та аудиту); екологічні експедиції "Чиста Говерла", прибирання парку "Знесіння", парку "Піскові озера" (навчально-наукові інститути екологічної економіки, лісового та садово-паркового господарства) - це заходи, яких було вжито за останні 2-3 роки.

Своєрідною платформою інновацій для національно-патріотичного виховання студентської молоді в університеті стала науково-технічна бібліотека (Beh \& Kuruchenko, 2016). Популяризація літератури, висвітлення важливих історичних подій $з$ життя українського народу, активна участь у загальноуніверситетських заходах, залучення працівників та студентства до виховних акцій у соціальних мережах, волонтерська діяльність - це не повний перелік того, що роблять працівники бібліотеки у цій важливій ділянці роботи. У рамках Всесвітнього дня Землі (2017р.) сформувався проект, який назвали Марш парків. До цієї події підготовлено тематичну книжкову виставку "Заповідники та національні парки", яку експонували як у науковому залі бібліотеки, так і у віртуальному середовищі. До Дня Землі (2017 р.) науково-технічна бібліотека долучилася до флешмобу "Перетворимо Землю на квітник", який проводила Українська кліматична мережа.

Наукові читання до 150-річчя від дня народження А. Шептицького та перший Львівський Екологічний форум організовано в університеті, були визнанням важливості екологізації освіти та виховання. Потрібно також відзначити активну участь викладачів та студентської молоді у заходах виховного характеру, які проводяться у Львові.

Істотну роль у духовно-патріотичному вихованні молоді відіграє і відкритий у 2011 р. студентський храм рівноапостольного князя Володимира. Священики беруть активну участь в урочистих академіях, організовують студентів на майстер-класи, а також перебувають у постійному пошуку нових форм роботи на виховній ниві (прощі для студентів та викладачів, перегляд фільмів просто неба та ін.).

Візитною карткою та хранителем університетських традицій є Народна хорова капела "Діброва" та ансамбль народного танцю "Полонина", що функціонують при Народному домі. Сподіваємось, що своєрідним культурним центром в університеті стане арт-студія, яка поєднуватиме і функції музею історії університету, і виставкового залу для студентських та викладацьких проектів.

Водночас, у виховній роботі є ще чимало проблем. Серед них низька активність студентів під час вживання виховних заходів, пасивність окремих викладачів. Потребує уваги координація виховної роботи кафедр гуманітарно-соціальних дисциплін та дирекцій інститутів. Необхідно вдосконалити роботу кураторів і органів студентського самоврядування під час проведення адаптаційного курсу, та підвищення їх ролі в національно-патріотичному вихованні студентів.

Процес виховання у закладі вищої освіти технічного/лісотехнічного профілю не має бути зосереджений суто на професійній зацікавленості, але має бути тісно пов'язаний із майбутнім молодих людей. Тому дуже важливим є у виховному процесі той факт, що активна участь студентів у позанавчальному житті університету також сприяє формуванню у них Soft Skills (м'яких навичок), в яких зацікавлені сучасні роботодавці.

Кожен студент, як і кожна нація, розвиваються у просторі й часі. I те, куди вони рухатимуться у перспективі, задається лінією їхнього розвитку сьогодні. Якщо бачення цієї лінії немає, якщо відсутнє виховання, то молоду людину можна легко скерувати куди завгодно. "Сучасна молодь - це генерація, що вимагає більш конструктивних і динамічних еволюційних кроків щодо розвитку суспільства; покоління людей, які бажають вчитися, працювати; врешті, генерація людей гарячих, радикально налаштованих, які не сприймають будь-яку фальш, нещирість, пусті обіцянки стосовно свого сьогодення і майбуття. Головна мета їхнього виховання - це набуття молоддю соціального досвіду, готовності до виконання громадянських і конституційних обов'язків, успадкування духовних надбань українського народу, досягнення високої культури взаємин, формування особистісних рис громадянина Української держави" (Kolyada, 2016).

Висновки. Сьогоднішні події на сході України стали своєрідним докором усім освітянам за недоопрацювання на ниві національно-патріотичного виховання. Зрозуміло, що патріотами не народжуються, ними стають, їх виховують. Цю роботу потрібно налагодити на всіх рівнях, застосовуючи найновіші та найпопулярніші форми і методи. Формуючи світогляд студентів, ми вносимо вагому частку в загальнодержавну справу виховання нового покоління українського народу, вшановуємо пам'ять про тих, хто віддав своє життя за незалежну Україну, хто сьогодні обороняє тї на Сході, і отримуємо гарантії майбутнього існування української нації. Усвідомлюючи свою відповідальність за майбутнє України, всупереч труднощам і перешкодам, ми зобов'язані знайти і методи, і нові форми виховної роботи, і підхід до студентів, і виконати поважну місію викладача і патріота своєї Батьківщини. Тому тема виховання студентської молоді в закладах вищої освіти потребує подальшого дослідження, зокрема через призму взаємодії технічного складової у діяльності вищого навчального закладу та гуманізації освітнього та виховного процесу в університеті.

\section{Перелік використаних джерел}

Beh, I., \& Kuruchenko, V. (2016). With Ukraine in the heart (training of the patriotic education of children and youth). Kharkiv. [In Ukrainian].

Kolyada, N. (2016). National and patriotic education of students in the terms of Institutions of Higher Education. Materialu Vseukrainskogo naukovo-praktuchnogo seminaru, (pp. 43-47). Kyiv. [In Ukrainian].

Korkishko, O. H., \& Palatkin, Ye. V. (2017). Extracurricular work on civic education of youth in terms of a higher educational institution. Dukhovnist osobystosti: metodolohiia, teoriia i praktyka, 6, 106116. [In Ukrainian]. 
Nakaz. (1993). The Order of Ministry of Education of Ukraine "On the improvement of management of educational work", № 395. [In Ukrainian].

Nakaz. (2016). The Order of Ministry of Education of Ukraine "The conception of national and patriotic education of children and youth". [In Ukrainian].

Pashkov, A., Trofimov, A., \& Myzuchyk, T. (2016). The forming of students' ecological culture as a way of humanization of the relationship with nature. Teoriya $i$ praktuka suchacnogo prurodoznavstva, (pp. 175-177). Kherson. [In Ukrainian].

Petko, L. V. (2017). The unity of teaching and educating in the forming professionally-orientated foreign-language community in the terms of university. Kyiv: Talcom. Retrieved from: http://enpuir.npu.edu.ua/handle/123456789/18513. [In Ukrainian].

Popova, O. (2017). The role of education in the forming of modern national identity. (Ser. Kulturolohiia). Naukovi zapysky Natsionalnoho universytetu Ostrozka akademiia, 18, 224-225. [In Ukrainian].

Postanova. (1993). The Decree of Cabinet of Ministers of Ukraine "The state national program "Education", № 896. [In Ukrainian].
Prokofyeva, L. B. (2017). Formation of aesthetic culture of students of higher educational institutions in the process of non-auditing work by means of decorative arts and crafts. Virtus, 101. [In Ukrainian].

Sopivnyk, R. V. (2016). Planning educational work in higher education. (Ser. Pedagogy, Psychology, Philosophy). Scientific Journal of National University of Life and Environmental Sciences of Ukraine, 239, 229-234. [In Ukrainian].

Ukaz Prezydenta Ukrainy "Pro osnovni napryamu reformyvannya vushoi osvity" (1995). [The Order of the President of Ukraine "On basic directions of the higher education reforming"]. № 832/95. [In Ukrainian].

Ukaz. (2015). The Order of the President of Ukraine "On the strategy of national and patriotic educating of children and youth for 20162020", 580/2015. Retrieved from: http://oblosvita.te.ua/images/ doc16/StrategijaUkaz.pdf. [In Ukrainian].

Zakon. (1991). The Law "On Education" of Ukraine. Vidomosti Verhovnoi Radu URSR, 34, 451 p. [In Ukrainian].

Zakon. (2017). The Law "On Education" of Ukraine. Vidomosti Verhovnoi Radu, 38-39, 380 p. [In Ukrainian].

Л. Б. Шептицкая, Н. Г. Захарчин, А. А. Чаплик

Национальный лесотехнический университет Украины, г. Львов, Украина

\section{СИСТЕМА НАЦИОНАЛЬНО-ПАТРИОТИЧЕСКОГО ВОСПИТАНИЯ В ВЫСШЕМ УЧЕБНОМ ЗАВЕДЕНИИ ЛЕСОТЕХНИЧЕСКОГО ПРОФИЛЯ}

Учитывая потребности времени и важность формирования мировоззрения молодежи, на примере Национального лесотехнического университета Украины прослежен процесс формирования системы национально-патриотического воспитания студентов на протяжении периода его становления. Опираясь на нормативно-правовые акты, обоснована необходимость создания Совета по организации воспитательной работы и привлечения к этой работе Координационного совета кафедр гуманитарно-социальных дисциплин и других подразделений университета. Определены основные направления воспитания студентов: национально-гражданский, военно-патриотический, экологический, гражданско-правовой и др., особая роль среди них отведена экологическому направлению. Приведены примеры основных форм проведения воспитательных мероприятий в университете. Доказана необходимость активизации дальнейшей работы в направлении национально-патриотического воспитания. Определена работа коллектива университета в поиске новых форм и методов проведения воспитательных мероприятий и решения проблемы преодоления пассивности и инертности части студенческой среды. Утверждается, что активное участие студентов во внеучебной жизни университета также способствует формированию у них Soft Skills (мягких навыков), в которых заинтересованы современные работодатели. Акцентировано внимание на перспективе создания арт-студии и молодежного центра для сотрудничества студент-преподаватель на воспитательном поприще.

Ключевые слова: воспитание; национально-патриотическое воспитание; экологическое воспитание; НЛТУ Украины.

L. B. Sheptytska, N. G. Zakharchyn, O. A. Chaplyk Ukrainian National Forestry University, Lviv, Ukraine

\section{THE SYSTEM OF NATIONAL AND PATRIOTIC EDUCATION IN HIGHER EDUCATIONAL INSTITUTIONS OF FORESTRY}

Considering the needs of the time and the importance of the youth's worldview formation, by the example of Ukrainian National Forestry University, the process of organization of the system of national and patriotic education of the students at higher education institutions of forestry is shown in the article. Since the time of obtaining the status of university and up till now the national patriotic education has been considered to be a priority, directed to the intelligentsia education with active stands in life creation of the condition for the development of general culture of the student youth. Based on the legal and regulatory acts, the need is justified for creation of the Board on the organization of educational work and the involvement of the Coordinating Board of the department of the humanities and the other subdivisions of the University. Inherently implemented common policy of education and training is shown in the "Plans of work and events concerning the realization of the concept of national and patriotic education of UNFU students", which is annually approved by the Rector of the University. The authors have outlined main approaches to students' education such as national and public, military and patriotic, ecological, civil and legal, etc. A special role is assigned to ecological approach in particular. The main forms of educational events held at the University are described in the article. The need for further intensification of work regarding the national and patriotic education is proved. The activity of the University staff in search of new forms and methods of educational events conducting and solution to the problem for overcoming indifferent attitude to educational issues of some part of students are highlighted. Great attention is focused on the creation of the art-studio and the youth centre for the student-teacher collaboration in the educational sphere. It is confirmed that active students promote the formation of their soft skills in their extra-educational life, in which modern employers are interested. Therefore, the issues related to the education of student youth in higher education institutions require further studying, especially by means of interaction of technical component in the activity of higher education institution with humanization of educational and learning process at University as well.

Keywords: education; national and patriotic education; ecological education; Ukrainian National Forestry University. 